\title{
PENINGKATAN KETERAMPILAN MENULIS MELALUI STRATEGI KOOPERATIF TIPE STAD
}

\begin{abstract}
Jusniati*
ABSTRACT

This study aims to describe (1) planning to improve writing skill through cooperative STAD type cooperative strategy of class XII IPA 4 SMA Negeri 1 Pasangkayu Pasangkayu Regency; (2) the implementation of improving writing skill through STAD type cooperative stategi I IPA 4 SMA Negeri 1 Pasangkayu Pasangkayu regency, and (3) assessment improving writing skill through cooperative type STAD strategy of grade XII students IPA 4 SMA Negeri 1 Pasangkayu. This research is a type of Classroom Action Research (PTK). This research was conducted at SMA Negeri 1 Pasangkayu Pasangkayu Regency that is class XII IPA4. This research data in the form of quantitative data that is result of student writing (essay) and qualitative data collected by using instrument. The instrument of this research is test and nontes, type of test used is writing activity, while nontes in the form of observation guidance, documentation study, and interview. The result of the research shows that in improving writing skill through STAD type cooperative stategial strategy IPA 4 SMA Negeri 1 Pasangkayu Pasangkayu regency in the stage of planning, implementation, and assessment of cycle I have not maximized because of obstacles faced by teachers and students in learning. However, in the second cycle of implementation planning, and assessment can be maximized with the limitation of all the obstacles experienced in the first cycle so that students' writing skills have a good change. or increase. Thus, STAD type cooperative strategy can improve the writing skill of grade XII students IPA4 SMA Negeri 1 Pasangkayu Pasangkayu regency.
\end{abstract}

Keywords : Improvement, Writing Skills, STAD Type Cooperative Strategy

*) Prodi Pendidikan Bahasa Indonesia, STIT DDI Pasangkayu E-mail: jusniatihasyim@gmail.com

\section{PENDAHULUAN}


Keterampilan menulis sebagai suatu keterampilan berbahasa produktif merupakan suatu hal yang paling kompleks yang membutuhkan beberapa syarat penguasaan kosakata, katatabahasaan, keterampilan menyusun dan merangkaikan gagasan, serta mengembangkan gagasan dalam suatu kebutuhan yang logis, padat danmudah dipahami. Oleh karena itu, siswa sangat dituntut dapat menguasai aspek-aspek yang memuat dalam keterampilan menulis agar dapat menerangkan gagasannya secara terpadu dan dalam bahasa yang dapat dimengerti oleh pembacanya.

Kegitan menulis merupakan kegiatan yang dapat menggunakan proses berpikir. Proses berpikir tersebut dilakukan penulis dalam dua hal, yakni apa dan bagaimana cara menulis. Apa yang ditulis berkaitan dengan gagasan atau materi yang akan ditulis, sedang bagaimana cara menulis berkaitan dengan pengembangan gagasan. Proses menggali materi yang akan ditulis dilakukan melalui kegiatan pemilihan topik, pengumpulan bahan, perencanaan penataan tulisan, penetapan tujuan menulis dan pengembangan gagasan. Sejalan dengan pernyataan tersebut, Enre (1994) mengatakan bahwa salah satu tugas penting seorang penulis ialah menguasai cara menulis dan berpikir akan banyak membantu dalam usaha pencapaian suatu tujuan yang penting.

Hasil pengamatan menunjukkan bahwa tidak sedikit siswa kurang menyukai pembelajaran menulis dikarenakan oleh sulitnya mengorganisasikan ide tulisannya dengan tepat. Siswa menganggap bahwa menulis membutuhkan kelengkapan syarat yang harus dipenuhi sehingga menjadi beban hasil moril yang ditanggung. Kondisi ini memungkinkan terciptanya minat rendah terhadap kegiatan pembelajaran menulis, khususnya pembelajaran menulis karangan siswa kelas XI IPA 4 SMAN 1 Pasangkayu di Kabupaten Pasangkayu.

Hal tersebut kemungkinan disebabkan oleh strategi yang digunakan oleh guru tidak menarik dan kurang variatif. Keterampilan menulis merupakan aspek yang cukup rumit karena keterampilan ini mencakup keterampilan yang lebih khusus di antaranya menyangkut pemakaian ejaan, diksi, kosakata, kohesi, koherensi, dan struktur kalimat serta penyusunan paragraf.

Salah satu strategi pembelajaran yang diharapkan dapat membantu pembelajaran menulis adalah strategi pembelajaran kooperatif. Slavin yang dikutif Sanjaya (2007:5) menyatakan dua alasan dianjurkannya pembelajaran kooperatif, yakni pertama, beberapa hasil penelitian menunjukkan bahwa penggunaan pembelajaran kooperatif dapat meningkatkan prestasi belajar siswa sekaligus juga dapat meningkatkan hubungan sosial, menumbuhkan sikap menerima kekurangan diri dan orang lain, serta dapat meningkatkan harga diri. Kedua, pembelajaran kooperatif dapat merealisasikan kebutuhan siswa dalam 
belajar berpikir, memecahkan masalah, dan mengintegrasikan pengetahuan dengan keterampilan.

Pembelajaran kooperatif merupakan model pembelajaran dengan menggunakan sistem pengelompokan / tim kecil, yaitu antara empat sampai enam orang yang mempunyai latar belakang Keterampilan akademik, jenis kelamin, rasa atau suku yang berbeda (heterogen). Sistem penilaian dilakukan terhadap kelompok. Setiap kelompok akan memperoleh penghargaan (reward), jika kelompok mampu menunjukkan prestasi yang dipersyaratkan (Sanjaya, 2007:7).

Strategi pembelajaran kooperatif tipe STAD dapat meningkatkan pembelajaran keterampilan menulis siswa. Hal tersebut dikarenakan karakter pembelajaran kooperatif tipe STAD memperlakukan siswa secara kelompok dan diberikan keluwasan dalam menuangkan gagasan/ide secara tulisan.

Keterampilan menulis yang baik dan teratur dalam menuangkan gagasan dalam proses pembelajaran tidak diperoleh secara otomatis, akan tetapi melalui latihan, praktik yang banyak dan teratur, serta cara atau strategi pembelajaran yang tepat. Dengan latihan dan praktik secara teratur STAD, maka hasil belajar pun akan lebih optimal dan terkontrol.

Sejalan dengan hasil penelitian tentang kemampuan berbicara yang pernah dilakukan oleh peneliti sebelumnya antara lain oleh Arafah (2001), yang meneliti tentang kemampuan berbicara siswa dengan menggunakan format multi arah di laboratorium bahasa. Hasil penelitian tersebut menunjukkan bahwa format komunikasi multi arah dapat meningkatkan hasil perolehan berbicara dan menarik minat siswa untuk berbicara. Selanjutnya, Halima (2006) yang meneliti tentang penerapan starategi pembelajaran kooperatif tipe STAD, dalam pembelajaran berbicara. Hasil penelitian penerapan strategi pembelajaran kooperatif tipe STAD dapat meningkatkan kemampuan berbicara siswa yang meliputi ketepatan pelafalan, pilihan kata, tatabahasa, dan kefasihan berbicara.

Selanjutnya penelitian kemampuan menulis juga pernah dilakukan oleh peneliti sebelumnya, penelitian yang dilakukan oleh Saleh ( 2007) mengkaji kemampuan siswa menulis karangan diskripsi dengan menggunakan pendekatan proses siswa SMA Negeri 1 Tamalatea. Hasil penelitian tersebut menunjukkan bahwa pendekatan proses dapat meningkatkan kemampuan siswa. Selanjutnya Amirullah (2006) mengkaji penetapan metode inkuiri dalam pembelajaran menulis karangan diskripsi pada siswa SMA Negeri 1 Binamu Jeneponto, Hasil penelitian tersebut menunjukkan bahwa penerapan pembelajaran inkuiri dapat meningkatkan keterampilan menulis karangan deskripsi serta motivasi belajar siswa. Masalah peningkatan kemampuan menulis penting diteliti, karena 
berdasarkan studi pendahuluan yang telah dilakukan oleh peneliti di sekolahsekolah. Penerapan strategi kooperatif tipe STAD dapat meningkatkan keterampilan menulis belum pernah dilakukan oleh SMA Negeri 1 Pasangkayu. Namun yang pernah dilakukan oleh guru selama ini hanya memberikan tugas kepada siswa untuk menulis tanpa menggunakan strategi yang mampu meningkatkan keterampilan menulis siswa.

Mengacu pada kenyataan dan pernyataan di atas, peneliti terdorong untuk mengadakan penelitian peningkatan keterampilan menulis karangan argumentasi melalui strategi pembelajaran kooperatif tipe STAD pada siswa

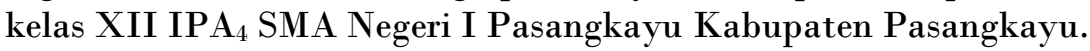

\section{Keterampilan Menulis}

Menulis pada hakekatnya menyampaikan ide atau pesan dengan menggunakan lambang grafik (tulisan) kepada orang lain. Dalam kegiatan menulis sesorang juga dituntut untuk menguasai komponen-komponen tulisan yang meliputi isi (materi) tulisan, organisasi tulisan, kebahagiaan, (kaidah bahasa tulis), gaya penulisan, dan mekanisme tulisan (Mulyati, 2012: 14).

Menulis adalah rangkaian proses berpikir. Proses berpikir berkaitan erat dengan kegiatan penalaran. Penalaran yang baik dapat menghasilkan tulisan yang baik pula, bahkan tempat penalaran tidak akan ada pengetahuan yang benar, Syafi'ie (2008: 182) mengemukakan bahwa salah satu substansi retorika menulis adalah penalaran yang baik. Dalam hal ini, berari untuk menghasilkan kesimpulan yang benar harus dilakukan penalaran secara cermat dengan berdasarkan pikiran yang logis. Penalaran yang salah akan menuntun kepada kesimpulan yang salah.

Pada dasarnya menulis merupakan proses pengungkapan ide atau gagasan, pikiran, pengalaman, perasaan dengan menggunakan bahasa sebagai medianya. Hal-hal-hal yang dikemukakan dalam tulisan bersumber dari pengalaman pribadi, pengalaman orang lain, atau dari membaca buku. menulis seperti halnya berbicara, merupakan keterampilan berbahasa yang produktif dan ekspresif. Perbedaannya, kegiatan menulis merupakan satu keterampilan berbahasa yang dapat menggunakan untuk berkomunikasi secara tidak langsung, tidak secara tatap muka dengan orang lain (tidak langsung), sedangkan berbicara merupakan tatap muka (langsung) (Tarigan, 2008: 12). 


\section{Pembelajaran Kooperatif}

Pembelajaran kooperatif adalah salah satu bentuk pembelajaran yang berdasarkan faham kontruktivis. Pembelajaran kooperatif merupakan strategi belajar dengan sejumlah siswa sebagai anggota kelompok kecil yang tingkat keterampilannya berbeda. Dalam menyelesaikan tugas kelompoknya, setiap siswa anggota kelompok harus saling bekerja sama dan saling membantu untuk memahami materi pelajaran. Dalam pembelajaran kooperatif, belajar dikatakan belum selesai jika salah satu teman dalam kelompok menguasai bahan pelajaran.

Unsur-unsur dalam pembelajaran kooperatif adalah sebagai berikut (Lungdren, 2014).

1. Para siswa harus memiliki persepsi bahwa mereka harus saling bekerja sama.

2. Para siswa harus memiliki tanggung jawab terhadap siswa atau peserta didik lain dalam kelompoknya, selain tanggung jawab terhadap diri sendiri dalam mempelajari materi yang dihadapi.

3. Para siswa harus berpandangan bahwa mereka semua memiliki tujuan yang sama.

4. Para siswa membagi tugas dan berbagi tanggung jawab di antara para anggota kelompok.

5. Para siswa diberikan satu evaluasi atau penghargaan yang akan ikut berpengaruh terhadap evolusi kelompok.

6. Para siswa berbagai kepemimpinan semesntara mereka memperoleh keterampilan bekerja sama selama belajar.

7. Setiap siswa akan diminta mempertanggungjawabkan secara individual materi yang ditangani dalam kelompok kooperatif.

Pembelajaran kooperatif siswa belajar bersama dalam kelompokkelompok kecil yang saling membantu satu sama lain. Kelas disusun dalam kelompok yang terdiri atas empat atau enam orang siswa, dengan keterampilan yang heterogen. Maksud kelompok heterogen adalah tediri atas campuran keterampilan siswa, jenis kelamin, dan suku. Hal ini bermanfaat untuk melatih siswa menerima perbedaan dan bekerja sama dengan teman yang berbeda latarbelakangnya.

Pada pembelajaran kooperatif diajarkan keterampilan-keterampilan khusus agar dapat bekerja sama dengan baik di dalam kelompoknya, seperti menjadi pendengar yang baik, siswa diberi lembar kegiatan yang berisi pertanyaan atau tugas yang direncanakan untuk diajarkan. Selama kerja kelompok, tugas anggota kelompok adalah mencapai ketuntasan (Slavin, 2005). 


\section{Pembelajaran Kooperatif Tipe STAD}

Student Team-Achievement Devision (STAD) merupakan tipe pembelajaran kooperatif yang paling sederhana. Kesederhanaannya pada belajar kelompok, setiap kelompok haruslah heterogen yang memiliki keterampilan tinggi, sedang, dan rendah. Setiap anggota 1 minggu atau 2 minggu siswa diberi kuis, kuis itu diskor dan tiap individu diberi skor perkembangan.

Skor perkembangan ini tidak didasarkan skor mutlak siswa, tetapi berdasarkan seberapajauh skor itu melampaui skor rata-rata siswa yang lain.

Dalam penerapan pembelajaran kooperatif dengan tipe STAD ini, pembelajaran harus melalui beberapa tahap sebagai berikut ini.

\section{1) Persiapan}

a) Materi

Materi pembelajaran kooperatif dengan tipe STAD dirancang sedemikian rupa untuk pembelajaran secara berkelompok. Sebelum menyajikan materi pembelajaran, dibuat lembar kegiatan dan lembar jawaban yang akan dipelajari oleh siswa dalam kelompok-kelompok kooperatif.

\section{b) Menetapkan siswa dalam kelompok-kelompok kooperatif}

Kelompok-kelompok dalam pembelajaran kooperatif dengan tipe STAD beranggotakan 4-6 orang yang terdiri atas siswa yang pandai, sedang dan kurang. Dalam kelompok juga dipertimbangkan hetergenitas jenis kelamin, latar belakang sosial, kesenangan dan lain-lain.

berikut:

Beberapa petunjuk dalam menentukan kelompok kooperatif seperti

1. Merangking siswa, berdasarkan prestasi akademiknya di dalam kelas.

2. Menentukan jumlah kelompok, setiap kelompok sebaiknya beranggotakan 4-6 orang.

3. Membagi dalam kelompok, diusahakan setiap kelompok terdiri atas siswa yang heterogen.

c) Menentukan skor awal

Skor awal merupakan skor rata-rata siswa secara individual pada tes sebelumnya. Tes ini berupa tes menulis.

\section{d) Menyiapkan siswa untuk belajar kooperatif}

Sebelum memulai kegiatan pembelajaran kooperatif dengan tipe STAD, sebaiknya dimulai dengan menyiapkan siswa untuk belajar kooperatif dengan agar masing-masing kelompok lebih saling mengenal setiap kelompoknya. 


\section{2) Penyajian materi atau presentase kelas}

Kegiatan pembelajaran kooperatif dengan tipe STAD mulai dengan penyajian materi pelajaran, dengan penekanan tahap demi tahap sebagai berikut:

\section{a) Pendahuluan}

Pada pendahuluan ini ditekankan pada apa yang dipelajari siswa dalam kelompok dan diinformasikan mengapa hal itu penting, ditujukan untuk memotivasi rasa ingin tahu siswa tentang konsep-konsep yang mereka pelajari.

\section{b) Pengembangan}

1. Mengembangkan materi pelajaran, sesuai dengan bahan yang dipelajari siswa dalam kelompoknya;

2. Pembelajaran kooperatif menekankan bahwa belajar adalah memahami makna dan bukan hanya menghapal;

3. Sering mengontrol pemahaman siswa dengan memberi pertanyaanpertanyaan secara acak;

4. Memberi jawaban mengapa jawaban itu benar dan salah;

5. Beralih pada konsep yang lain bila siswa telah memahami pokok masalah.

\section{c) Latihan terbimbing}

1. Menyuruh siswa menjawab soal-soal atau memberimemberi jawaban atas pertanyaan-pertanyaan yang diberikan;

2. Memanggil siswa secara acak untuk menjawab pertanyaan atau soal-soal agar siswa selalu mempersiapkan diri sebaik-baiknya;

3. Pemberian tugas dengan waktu pengerjaan terbatas, kemudian diberi umpan balik.

d) Kegiatan kelompok

1. Pada kegiatan pertama kerja kelompok dengan pembelajaran kooperatif, sebaiknya guru menjelaskan apa yang dimaksud bekerja dalam kelompok. Sebelum memulai bekerja hendaknya guru menetapkan peraturan dalam kelompok kooperatif;

2. Siswa mempunyai tanggung jawab untuk memastikan bahwa teman sekelompoknya telah mempelajari materi;

3. Tidak seorang pun siswa belajar sebelum semua anggota kelompok menguasai materi pelajaran;

4. Meminta bantuan dari teman satu kelompok sebelum meminta bantuan dari guru;

5. Dalam satu kelompok harus berbicara sopan.

Untuk kegiatan kerja kelompok, guru membagikan LKS kepada setiap kelompok sebagai bahan yang akan dipelajari siswa, di samping untuk 
mempelajari konsep-konsep materi pelajaran, LKS juga untuk melatih keterampilan.

1. Dalam kegiatan kerja kelompok siswa mengerjakan tugas-tugas secara mandiri dan selanjutnya saling mencocokkan jawabannya dengan teman kelompoknya. Jika ada seorang siswa belum memahami materi, maka teman kelompoknya bertanggung jawab untuk menjelaskannya. Sebelum bertanya kepada guru, sebaiknya masalah dipecahkan dengan teman kelompoknya;

2. Dalam kegiatan kelompok guru bertindak sebagai fasilitator yang memonitor kegiatan masing-masing kelompok.

e) Evaluasi

Evaluasi dikerjakan secara mandiri. Siswa harus menunjukkan apa yang telah ia pelajari secara individual selama berkerja dalam kelompoknya. Hasilnya juga akan diseimbangkan sebagai nilai perkembangan kelompok.

f) Penghargaan kelompok

Dalam memberikan penghargaan kelompok, dapat dilakukan dengan mencari nilai rata-rata dari skor tes masing-masing anggota kelompok dan merangkinnya, sehingga ada kelompok sebagai juara I, juara II, dan juara III. Penghargaan dapat berupa sertifikat atau hadiah.

\section{METODE PENELITIAN}

\section{a. Jenis Penelitian}

Jenis penelitian ini adalah penelitian tindakan (action research). Karena dilakukan di sekolah (kelas) maka termasuklah jenis PTK (CAR). Rofi'udin (2002:15) menyatakan, "Penelitian tindakan kelas memiliki ciri-ciri: (1) bersifat kolaboratif, (2) berfokus pada problem praktis, (3) penekanan pada pengembangan profesional, dan (4) memerlukan adanya struktur proyek yang memungkinkan partisipan untuk berkomunikasi”". Penelitian ini dilaksanakan di kelas XII IPA ${ }_{4}$ SMAN I Pasangkayu.

\section{b. Desain Penelitian}

Desain penelitian mengacu pada alur Penelitian Tindakan Kelas model Kemmis dan Mc. Taggart, yaitu berupa perangkat yang terdiri dari empat komponen, yaitu perencanaan, tindakan, pengamatan, dan refleksi. Keempat komponen tersebut yang berupa untaian dipandang sebagai satu siklus. Siklus adalah suatu putaran kegiatan yang terdiri dari perencanaan, tindakan, pengamatan, dan refleksi.

\section{c. Tempat Dan Waktu Penelitian}


Subjek penelitian adalah peserta didik kelas kelas XII IPA 4 SMAN I Pasangkayu.

yang berjumlah 25 orang tahun ajaran 2017-2018 dan I orang guru mata pelajaran Bahasa Indonesia.

Waktu penelitian ini dilaksanakan pada semester Ganjil tahun pelajaran $2017 / 2018$.

\section{d. Teknik Pengumpulan Data}

Teknik pengumpulan data dalam penelitian melalui (1) studi pendahuluan, (2) perencanaan tindakan, (3) pelaksanaan tindakan, (4) pengamatan (observasi) dan (5) refleksi. Prosedur-prosedur tersebut dilaksanakan dalam tindakan yang berdaur ulang (siklus).

\section{e. Teknik Analisis Data}

Analisis data dilakukan berdasarkan teknik analisis data model Miles dan Huberman. Proses analisis data mengikuti langkah-langkah berikut:

\section{Tahap Menelaah Data}

Kegiatan menelaah data yang telah terkumpul berdasarkan hasil observasi, catatan lapangan, dan dokumen. Kegiatan menelaah data dilaksanakan dengan melakukan proses transkripsi hasil observasi, data nilai/hasil belajar siswa maupun hasil wawancara. Data yang telah ditranskripsikan dikelompokkan dengan masalah penelitian.

\section{Tahap Reduksi Data}

Reduksi data adalah proses penyederhanaan yang dilakukan melalui seleksi, pemfokusan, pengabtrasian data mentah menjadi informasi bermakna (Hasriati, 1995:15). Reduksi data dilakukan dengan meringkas data dalam satuan-satuan informasi sesuai dengan masalah penelitian.

\section{Tahap Penyajian Data}

Menyajikan data atau memaparkan data. Penyajian data dilakukan dengan menampilkan satuan-satuan informasi secara sistematis berdasarkan kategorinya sehingga memungkinkan peneliti menarik kesimpulan.

\section{Tahap Penyimpulan Data}

Penyimpulan data dilakukan dengan menafsirkan makna sesuatu fenomena yang terjadi selama tindakan berlangsung. Sebelum dilakukan penyimpulan akhir, terlebih dahulu dilakukan penyimpulan sementara. Penyimpulan sementara yang dilakukan peneliti diikuti dengan pengecekan keabsahan data, yaitu dengan ketekunan pengamatan, trianggulasi metode, dan pengecekan teman sejawat. Selanjutnya, peneliti menarik kesimpulan akhir 
setelah pengecekan keabsahan data melalui ketekunan data, trianggulasi metode, dan pengecekan teman sejawat mendukung kesimpulan sementara.

\section{HASIL DAN PEMBAHASAN}

\section{a. Perencanaan pembelajaran keterampilan menulis}

Berdasarkan hasil penelitian penerapan strategi kooperatif tipe STAD dalam pembelajaran menulis terungkap bahwa rencana pembelajaran yang

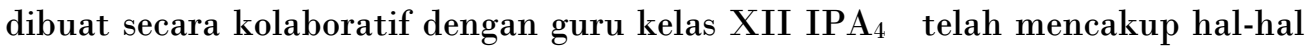
yang menjadi dasar penyusunan perencanaan pembelajaran. Dalam perencanaan terdapat unsur-unsur (1) standar kompetensi, (2) kompetensi dasar, (3) indikator, (4) tujuan, (5) materi pembelajaran, (6) metode pembelajaran, (7) skenario pembelajaran, (8) sumber bahan dan alat pembelajaran, dan (9) penilaian. Semua komponen tersebut terdapat dalam pembelajaran pada siklus I dan siklus II. Menurut Hamalik (1991:92) semua komponen itu dirancang secara rinci, spesifik, operasional, dan dapat dilaksanakan.

Perencanaan pembelajaran merupakan sangat penting dimiliki guru sebelum masuk ke kelas, perencanaan pembelajaran berfungsi sebagai pedoman konkret dalam melaksanakan pembelajaran. Hal itu sejalan dengan pernyataan Moenir, dkk. (1998:78) bahwa kegiatan perencanaan dalam pembelajaran dimaksudkan sebagai upaya menjamin belajar siswa dapat berjalan lancar dan efektif.

Rencana pembelajaran disusun berdasarkan standar kompetensi dan kompetensi dasar dalam kurikulum KTSP pada aspek keterampilan menulis. Rencana pembelajaran ini disusunn secara kolaboratif antara guru dan peneliti. Berdasarkan kompetensi dasar ditentukan indikator kemudian disusun tujuan pembelajaran. Dalam menentukan tujuan yang diharapkan tercapai dalam pembelajaran ini sejalan dengan pendapat Das dan Roedito (1980:14) yang menyatakan bahwa kriteria yang harus dipenuhi dalam merumuskan tujuan, ialah: (1) berorientasi kepada siswa, (2) bersifat menguraikan hasil belajar, (3) jelas dan dapat dimengerti, serta (4) dapat diobservasi dan diukur.

Tujuan pembelajaran berfungsi sebagai acuan awal untuk menentukan materi, memilih alat atau media, menentukan alat atau media, menentukan kegiatan belajar mengajar, dan menentukan cara atau alat penilaian. Sebagaiman dinyatakan Moenir, dkk. (1998:44) bahwa tujuan pembelajaran memegang posisi penting dalam menyusun rencana pembelajaran, karena rencana pembelajaran akan mempermudah penentuan materi, kegiatan belajar mengajar, media, dan alat evaluasi. 
Kegiatan selanjutnya adalah penetapan materi pembelajaran. Penetapan, pengembangan dan pengorganisasian materi, alasan fungsional, bakat, serta minat kemampuan dan kebutuhan siswa disesuaikan dengan tujuan pembelajaran. Pada penelitian ini peneliti dan guru secara kolaboratif memilih materi menyampaikan pendapat, ide, atau gagasan dengan menggunakan bukti, contoh, alasan yang tepat dengan menggunakan bahasa baik dan dan benar dalam karangan.

Materi pembelajaran yang dipilih disesuaikan dengan tujuan pembelajaran, indikator, dan kompetensi dasar. Penetapan materi dalam penelitian ini mamanfaatkan informasi dari media cetak. Pemilihan materi yang dikaitkan dengan penggunaan media dapat memacu kemampuan siswa dalam menulis (mengarang). Sejalan dengan itu, Nurhadi (2002:1) menyatakan bahwa sebaiknya guru mengaitkan antara materi yang diajarkan dan situasi dunia nyata siswa membuat hubungan antara pengetahuan yang dimilikinya dalam penerapannya dan kehidupan mereka sebagai anggora keluarga serta masyarakat.

Kegiatan belajar mengajar dalam perencanaan dijabarkan dalam langkah-langkah pembelajaran yang mencakup kegiatan awal, kegiatan inti, dan kegiatan akhir. Hal yang sangat berpengaruh dalam perencanaan pembelajaran adalah pembagian waktu. Pembagian waktu yang digunakan sangat membatu guru melaksanakan tugasnya dalam mengorganisasikan siswa. Selain langkahlangkah pembelajaran yang terdapat dalam perencanaan, penggunaan media pembelajaran juga perlu ditentukan karena media pembelajaran berperan sebagai pembawa pesan dalam rangka mencapai tujuan. Media yang dipergunakan dalam penelitian ini adalah bahan cetak. Media sangat terkait dengan siswa karena dapat meningkatkan motivasi dan kreativitas keterampilan menulis siswa. Hal ini sejalan dengan pernyataan Woolkfolk (dalam Dimyati dkk, 2002:36) yang menyatakan bahwa pemanfaatan media dalam pembelajaran dapat meningkatkan kegiataan pembelajaran sehingga mutu hasil belajar semakin meningkat.

Penilaian yang direncanakan dalam penelitian ini adalah penilaian proses dan penilaian hasil Penilaian proses dilakukan pada saat pembelajaran berlangsung. Hasil yang diperoleh dengan mengamati aktivitas guru dan siswa. Kegiatan pengamatan difokuskan pada aspek kerja sama, aktivitas dalam berbagi pendapat, unjuk kerja, minat, dan keantusiasan siswa mengikuti pelajaran.

Penilaian hasil direncanakan sesuai dengan tujuan pembelajaran yang telah dirumuskan. Dalam perencanaan penilaian hasil, dirumuskan rambu- 
rambu analisis hasil belajar siswa. Penilaian dilakukan nerdasarkan indikator yang telah ditetapkan. Nurgiyantoro (2001:102) menyatakan bahwa yang menjadi indikator keefektifan siswa dalam menulis adalah ketepatan menulis dengan memperhatikan ketepatan topik, menulis ide pokok, mengembangkan ide pokok, pilihan kata, kohesi, koherensi, kalimat utama, dan penggunaan EYD.

Hamalik (2003:135) menyatakan "Guru yang baik akan berusaha sedapat mungkin agar pengajarannya berhasil" Salah satu faktor yang dapat membawa keberhasilan guru adalah membuat perencanaan sebelum mengajar. Guru diharapkan lebih sistematis, efektif, dan efisien dalam melasanakan pembelajaran. Hal ini sejalan dengan pernyataan Kemp (1985:112) bahwa perencanaan pembelajaran yang disusun secara sistematis akan memberi manfaat dalam berbagai aspek. Manfaat yang dimaksud, yaitu (1) pengelolaan program memerlukan bukti yang terpercaya tentang proses beljaar yang efektif dan efisien, (2) perencanaan pengajaran memerlukan bukti bahwa program yang direncanaan memuaskan dengan indikator pencapaian semua tujuan progran oleh siswa dalam batas waktu yang tepat, (3) guru ingin memeroleh semua siswa kemampuan yang diharapkan dan mebina reaksi positif dengan siswa, dan (4) siswa ingin berhasil sekaligus mendapatkan pengalaman belajar yang menyenangkan dan memuaskan.

\section{b. Pembahasan pelaksanaan pembelajaran keterampilan menulis.}

Pelaksanaan pembelajaran keterampilan menulis melalui strategi kooperatif tipe STAD dilaksanakan tiga tahap kegiatan, yakni: (1) kegiatan awal, (2) kegiatan inti, dan (3) kegiatan akhir. Berdasarkan paparan data hasil penelitian. Pembelajaran diawali guru dengan melakukan apersepsi, pemberian motivasi, mengemukakan tujuan pembelajaran, proses pembelajaran, dan menjelaskan materi pembelajaran sebelum memasuki pembelajaran tahap inti.

Kegiatan apersepsi diberikan dengan cata tanya jawab dengan siswa, kemudian dilanjutkan dengan motivasi. Motivasi dilakukan bertujuan untuk membangkitkan keantusiasan belajar siswa belajar keterampilan menulis. Hal ini sejalan dengan pendapat Sardiman (1992:75) yang mengemukakan bahwa "motivasi dapar dikatakan serangkaian usaha untuk menyediakan kondisikondisi tertentu sehingga siswa ingin dan mau melakukan sesuatu". Jadi, motivasi merupakan faktor penentu keterlibatan siswa secara aktif dalam belajar.

Selanjutnya, kegiatan yang dilaksanakan guru adalah menyampaikan tujuan pembelajaran dan informasi proses pembelajaran termasuk proses pelaksanaan stategi kooperatif tipe STAD dalam pembelajaran. Penyampaian 
tujuan dalam pembelajaran sangat penting bagi siswa agar dalam pelaksanaan pembelajaran terjalin komunikasi yang aktif antara guru dan siswa. Hal ini sesuai pendapat Vygotsky (dalam Paul Eggel, 2006) mengatakan bahwa "Komunikasi antara guru dan siswa yang dilakukan dengan cara menyampaikan tujuan pembelajaran dapat menambah pemahaman siswa terhadap apa yang semestinya diperoleh dalam kegiatan belajar." Dalam sudut pandang kaum konstruktivistik, penyampaian tujuan pembelajaran yang cermat dapat membantu siswa dalam pembelajaran (Slavin, 1994:143). Jadi, meskipun siswa bebas, namun mereka tetap aktif berusaha membentuk pemahaman terhadap informasi berdasarkan hasil interaksi dengan konteks yang dihadapi.

Sebelum kegiatan dilaksanakan guru memberikan petunjuk mengenai tugas yang akan dilaksanakan pada setiap siswa dalam kelas berdasarkan proses pembelajaran kooperatif tipe STAD. Aktivitas selanjutnya sebelum berdiskusi adalah mengorganisasi siswa dalam kelompok dan meminta siswa membaca wacana. Kegiatan ini merupakan proses berpikir yang melibatkan kognitif secara optimal. Hal tersebut diperkuat oleh pendapat Olson (dalam Lukmann 2004:218) yang menyatakan bahwa kegiatan berdiskusi kadang-kadang tidak berhasil karena siswa tidak memiliki persiapan yang mencakup tentang cara merespon sejumlah pendapat dari teman dan tidak memahami cara menerima umpan balik teman sejawat. Jadi pelaksanaan diskusi perlu perencanaan secara matang agar siswa muda memahami apa yang akan dilaksanakan selama diskusi.

Penerapan tanya jawab yang dapat mengaktifkan siswa dalam kelas sebagai wjud tindak lanjut dari kegiatan guru menjelaskan pembelajaran yang dinilai kurang maksimal merupakan langkah positif yang dilakukan guru dalam penelitian ini. Dalam hal ini Suparno (1997) menegaskan bahwa proses belajar dapat berlangsung dengan baik jika guru memainkan peranan sebagai mediator dan fasilitator.

Kegiatan terakhir yang dilaksanakan dalam pembelajaran ini ialah siswa dan guru melakukan rangkuman dan merefleksi kegiatan yang telah dilaksanakan dan pemberian motivasi pada siswa agar selalu melatih diri dalam menulis (mengarang). Jadi, Motivasi tidak hanya diberikan pada kegiatan awal melainkan juga pada kegiatan akhir perlu diberikan motivasi agar siswa mampu mengembangkan dirinya melalui latihan.

Aktivitas siswa secara umum dalam penelitian ini terlihat siswa aktif berinteraksi dalam kelompoknya. Interaksi tersebut berupa tanya jawab, saling koreksi, memberi masukan, dan berlatih pada aspek menulis yang belum dikuasai siswa. Keaktifan siswa mencerminkan keberhasilan strategi kooperatif 
tipe STAD. Penggambaraan keberhasilan pembelajaran ini sejalan dengan unsur-unsur dasar pembelajaran kooperatif.

\section{SIMPULAN}

Ada empat simpulan yang berkaitan dengan perencanaan pembelajaran. Pertama, penggunaan strategi kooperatif tipe STAD dalam perencanaan pembelajaran keterampilan menulis disusun dan diwujudkan dalam bentuk rencana pembelajaran. Rencana pembelajaran disusun secara kolaboratif antara peneliti dan guru bahasa Indonesia kelas XII IPA4. Rencana pembelajaran disusun berdasarkan program semester I, yang terdiri dari (1) standar kompetensi, (2) kompetensi dasar, (3) indikator, (4) tujuan, (5) materi pembelajaran, (6) metode pembelajaran, (7) langkah-langkah pembelajaran, (8) sumber bahan/alat, dan (9) penilaian. Kedua, rencana disusun berdasarkan kurikulum. Selain itu, juga memperhatikan minat siswa. Ketiga, rencana disusun dengan memperhatikan proses pembelajaran. Proses pembelajaran keterampilan menulis menggunakan tahapan berikut, yaitu (1) tahap kegiatan awal, (2) kegiatan inti, dan (3) tahap kegiatan akhir. Keempat, rencana yang disusun memuat tugas-tugas pembelajaran secara jelas dan rinci. Hal ini berguna untuk membantu siswa dalam belajar.

\section{SARAN DAN REKOMENDASI}

Berdasarkan hasil kesimpulan penelitian dapat diajukan saran sebagai berikut.

1. Perencanaan yang lengkap dan sistematis dapat memudahkan guru memenejerial pembelajaran. Oleh karena itu, disarankan kepada guru secara umum dan guru bahasa Indonesia secara khusus untuk membuat perencanaan pembelajaran dengan baik sebelum melaksanakan pembelajaran.

2. Kepada guru bahasa Indonesia sebaiknya menggunakan strategi kooperatif tipe STAD ini dalam meningkatkan keterampilan menulis siswa dengan memperhatikan karaktersiswa dan menyesuaikan kondisi atau lingkungan sekolah yang bersangkutan.

3. Dalam meningkatkan pembelajaran keterampilan menulis siswa, guru hendaknya lebih banyak memberikan kesempatan untuk praktik kepada siswa. Selain itu dalam melaksanakan penilaian pembelajaran tidak hanya menilai hasi belajar siswa, tetapi juga menilai proses belajar siswa. 


\section{DAFTAR PUSTAKA}

Depdiknas. 2006. Kurikulum Sekolah Menengah Atas

Enre, Fahruddin Ambo. 2004. Dasar-dasar Keterampilan Menulis. Ujungpandang.

Fatmawati, 2005. Peningkatan Keterampilan Menulis. Ujung pandang

Hamalik Oemar. 2011. Strategi Belajar Mengajar Berdasarkan CBSA Bandung: Sinar Baru.

Hamalik, Oemar. 2003. Prose Belajar Mengajar.Bangung: Bumi Aksara.

Ibrahim, Muslimin, dkk. 2005. Pembelajaran Kooperatif. Universitas Surabaya. UNESA.

Lukman. 2004. Peningkatan Pembelajaran Menulis Wacana Ekspossitori melalui Strategi Writers' Workshop Siswa Kelas II SMP Negeri 2 Wawasangka. Tesis tidak diterbitkan. Malang: Program Pascasarjana Universitas Negeri Malang.

Lungdren. 1994. Lewood Cliffs, New Jersey: Preantice Hall.

Milles, M. B. dan Uberman, M. A. 1992. Analisis Data Kualitatif. Bandung. Penerjemah Tjetjep Rohendi Rohidi. Jakarta: Universitas Indonesia.

Moenir, M., dkk., 2012. Perencanaan Pembelajaran. Malang: FIP IKIP

Mulyasa, E. 2006. Kurikulum Satuan Pendidikan. Sebuah Pedoman Praktis. Bandung: Remaja Rosdakarya.

Mulyati, 2002. Keterampilan Menulis. Bandung: Remaja Rosdakarya.

Nurgiyantoro, Burhan. 2001. Penilaian dalam Pengajaran Bahasa dan Sastra Edisi Ketiga. Yogyakarta: BPFE

Nurhadi. 2002. Pendekatan Kontekstual. Malang: Universitas Negeri Malang.

Nursito, 2000. Penuntung Mengarang. Yogyakarta: Adicita Karya Nusa.

Paul Eggel. 2006. Psikologi Pendidikan. Terjemahan. Makassar: PPs UNM

Rafiuddin. 2002. Penelitian dalam Kelas. Jakarta: Gramedia

Sanjaya, Wina. 2007.a. Strategi Pembelajaran. Beriorientasi Standar Proses Pendidikan. Jakarta: Kencana.

Sanjaya, Wina. 2007.b. Strategi Pembelajaran. Beriorientasi Standar Proses Pendidikan. Jakarta: Kencana.

Sardiman. 1992. Interaksi dan motivasi Belajar. Jakarta: Rajawali

Slavin, R. 2005. Coopetative Learning: Theory Risearch and Practice. Masschusetts: Allyn and Bacon Publiser.

Suparno, Paul. 1997. Filsafat Konstuktivisme dalam Pendidikan. Yogyakarta: Kanisius

Syafii, Imam. 2008. Retorika dalam Menulis. Jakarta: Depdikbud. 
Vol. 14, No. 1, Mei 2018

Tarigan, Djago dan Henry Guntur Tarigan. 2008. Strategi Pengajaran dan Pembelajaran Berbahasa. Bandung: Angkasa.

Tarigan, Djago dan Henry Guntur Tarigan. 2008. Teknik Pengajaran Keterampilan Berbahasa. Bandung: Angkasa. 